\title{
UPAYA-UPAYA PETANI PADI SEKITAR DAERAH PARIWISATA PANGANDARAN DI ERA COVID-19 \\ (Studi Kasus Desa Cibenda, Kecamatan Parigi, Kabupaten Pangandaran)
}

\author{
THE EFFORTS OF RICE FARMERS AROUND PANGANDARAN TAOURISM \\ AREAS IN THE COVID-19 ERA \\ (Case Study OF Cibenda Village, Parigi District, Pangandaran Regency)
}

\author{
Ai Sri Hartati*, Yayat Sukayat \\ Program Studi Agribisnis Faperta Universitas Padjadjaran \\ *Email: sri17003@mail.unpad.ac.id \\ (Diterima 25-01-2021; Disetujui 03-06-2021)
}

\begin{abstract}
ABSTRAK
Pariwisata memiliki andil yang cukup besar dalam kontribusi perekonomian negara, pariwisata berkontribusi terhadap Produk Domestik Bruto (PDB) nasional. Pandemi covid-19 membuat seluruh pariwisata di Indonesia harus ditutup untuk menghindari penyebaran virus corona. Penutupan pariwisata dilakukan oleh pemerintah Kabupaten Pangandaran sebagai upaya untuk mengantisipasi penyebaran virus corona di Kabupaten Pangandaran. Tujuan penelitian adalah untuk mengetahui pengaruh pandemi covid-19 terhadap petani padi sekitar daerah pariwisata Pangandaran, dan untuk mengetahui upaya-upaya petani padi sekitar daerah pariwisata Pangandaran di era covid-19. Desain penelitian yang digunakan adalah kualitatif deskriptif dengan pendekatan studi kasus. Pengambilan data menggunakan metode wawancara secara langsung kepada informan. Hasil penelitian menunjukan bahwa covid-19 memberikan pengaruh terhadap petani padi sekitar daerah pariwisata Pangandaran. Dalam usahatani padi petani mengalami pengaruh yang paling besar terjadi pada tenaga kerja, pendistribusian pupuk dan pemasaran padi, hal tersebut disebabkan karena hotel, restoran dan rumah makan tutup sehingga mengakibatkan kesulitan dalam memasarkan padi. Dengan pengaruh tersebut maka petani melakukan beberapa upaya-upaya untuk dapat memenuhi kebutuhan sehari-hari. Upaya-upaya petani padi sekitar daerah pariwisata Pangandaran di era covid-19 yaitu upaya yang dilakukan pemerintah dan upaya yang dilakukan oleh petani sendiri. Upaya yang dilakukan pemerintah 1) Bantuan langsung tunai, 2) bantuan sembako, dan upaya yang dilakukan oleh petani sendiri, yaitu 1) pengurangan tenaga kerja, 2) menggunakan tenaga kerja keluarga, 3) pengurangan dosis pupuk, 4) meminjam uang ke tetangga atau non bank, 5) pengurangan penjualan padi, dan 6) menanam tanaman lain dengan jumlah penjualan yang dikurangi.
\end{abstract}

Kata Kunci: Pariwisata, Pandemi, Petani padi, Upaya

\begin{abstract}
Tourism has a significant share in the contribution of the country's economy, tourism contributes to the national Gross Domestic Product (GDP). The covid-19 pandemic has forced all tourism in Indonesia to be closed to avoid the spread of the corona virus. The closure of tourism was carried out by the Pangandaran Regency government, this effort was made to anticipate the spread of the corona virus in Pangandaran Regency. The research objective was to determine the effect of covid19 on rice farmers around the Pangandaran tourism area and to determine the efforts of rice farmers around the Pangandaran tourism area in the covid-19 era. The research design used is descriptive qualitative with a case study approach. Retrieval of data using the interview method directly to informants. The results showed that Covid-19 had an effect on rice farmers around the Pangandaran tourism area. In rice farming, farmers experience the greatest influence on labor, distribution of fertilizer and rice marketing, this is because hotels, restaurants and restaurants are closed, resulting in difficulties in marketing rice. With this influence, farmers make several efforts
\end{abstract}


to meet their daily needs. The efforts of rice farmers around the Pangandaran tourism area in the Covid-19 era are efforts made by the government and efforts made by the farmers themselves. Efforts made by the government 1) direct cash assistance, 2) basic food assistance and efforts made by the farmers themselves, namely 1) reduction of labor, 2) using family labor, 3) reducing fertilizer doses, 4) borrow moneyfrom neighbors or non-banks, 5) reducing rice sales, 6) planting other crops with reduced sales volume

Key words: Tourism, Pandemic, Rice farmers, Efforts

\section{PENDAHULUAN}

Letak Indonesia yang sangat strategis ini lah yang membuat Indonesia dikenal dengan sebutan Zamrud Khatulistiwa yang mempunyai pesona keanekaragaman dan memiliki banyak budaya. Berbagai keistimewaan yang dimiliki tersebut maka Indonesia mempunyai potensi yang dapat dikembangkan terutama pariwisata. Perkembangan pariwisata memiliki andil yang cukup besar dalam kontribusi peningkatan perekonomian negara.

Menurut Yoeti dalam Dhalyana dan Adiwibaya (2013), pariwisata merupakan salah satu sektor ekonomi alternatif yang dipandang dapat mempercepat dalam penanggulangan di Indonesia. Pada tahun 2010 sektor pariwisata telah menyumbang devisa sebanyak US\$ 4.63 miliar terhadap perekonomian negara (Bappenas, 2008).

Pariwisata berkontribusi terhadap Produk Domestik Bruto (PDB) nasional sebanyak 113,78 triliun rupiah pada athun 2004. Selain berkontribusi terhadap
PDB nasional, pariwisata memberikan kontribusi dalam menciptakan lapangan pekerjaan. Tahun 2004 pariwisata memberikan kontribusi lapangan pekerjaan sebanyak 8,49 juta orang atau 9,06\% dari total lapangan perkerjaan Indonesia. Perkembangan pariwisata tidak hanya dapat meningkatkan perolehan devisa negara, tetapi diharapkan mampu berperan sebagai katalisator pembangunan (Bappenas, 2008).

Jawa Barat merupakan salah satu provinsi yang mengembangkan potensi wisata di daerahnya. Jawa Barat memiliki 50 destinasi pariwisata nasional yang telah ditetapkan pada rencana induk pembangunan pariwisata nasional, tiga diantaranya berada di provinsi Jawa Barat yaitu Bogor-Halimun, Bandung Ciwidey dan Pangandaran. Dalam peraturan Gubernur Jawa Barat Nomor 48 tahun 2006, Jawa Barat menetapkan rencana induk pengembangan pariwisata (RIPPDA Jawa Barat). 
Jawa Barat bagian selatan sekarang menjadi wilayah yang mendapatkan perhatian yang khusus mengingat memiliki potensi sumber daya alam yang melimpah. Menurut Gumilar dalam Fauzi, Bakhri, Ahmad (2019) potensi tersebut dijadikan sebagai kawasan wisata andalan. Salah satu wisata andalan Jawa Barat yaitu wisata Pangandaran, kawasan tersebut memiliki beberapa daerah pengembangan pariwisata yang mempunyai potensial.

\section{Disahkannya Undang-Undang}

Nomor 21 tahun 2012, Kabupaten Pangandaran secara resmi telah terpisah dari Kabupaten Ciamis secara mandiri berdiri sendiri sebagai daerah otonomi yang baru. Disetujuinya Kabupaten Pangandaran sebagai daerah yang baru oleh pemerintah pusat, hal tersebut yang mengharuskan Kabupaten Pangandaran untuk mandiri salah satu dari kemandirian tersebut adalah dari sisi ekonomi dan pembiayaan daerah. Menurut Kuncoro dalam Fauzi, Bakhri, Ahmad (2019), pemekaran suatu daerah mempunyai alasan yang utama untuk dapat meningkatkan kesejahteraan rakyat, karena kecenderungan yang sering terjadi yaitu sumber daya yang ditarik oleh daerah induk sehingga daerah yang jauh dari pusat cenderung mengalami ketertinggalan.

Pada tahun 2012 sektor pertanian di Kabupaten Pangandaran memiliki kontribusi yang besar dalam pendapatan daerah sebesar 27,52\%. Sedangkan untuk sektor pedagangan, hotel dan resoran memiliki kontribusi yang rendah dibandingkan dengan sektor pertanian. Namun dengan seiring waktur di sektor pertanian, perikanan, perternakan dan kehutanan mengalami pergeseran dibandingkan dengan tahun sebelumnya, sedangkan pada sektor perdagangan, hotel dan restoran mengalami peningkatan (RPIJM 2016-2021).

Sektor pertanian di Kabupaten Pangandaran masih menjadi penggerak roda perekonomian, sehingga dapat mempengaruhi laju pertumbuhan ekonomi yang signifikan. Pemerintah Kabupaten Pangandaran masih berfokus terhadap pengembangan sektor pertanian. Cakupan sektor pertanian meliputi tanaman pangan, perikanan, peternakan, kehutanan dan perkebunan.

Secara umum salah satu sub sektor yang dominan di Kabupaten Pangandaran adalah tanaman padi, dengan luas panen 33.375 hektar pada tahun 2016 naik sebesar 3,97\% dibandingkan dengan tahun sebelumnya. Produksi padi pada 
tahun 2016 sebesar 189.990 ton, mengalami peningkatan dari tahun sebelumnya sebanyak 134.896 ton. Padi sawah menyumbang sebesar 187.486 ton atau $98,68 \%$ dan sisanya berasal dari padi ladang sebesar $\quad 1,32 \% \quad$ (Kabupaten Pangandaran Dalam Angka 2019).

Ketersediaan pangan di Kabupaten Pangandaran mampu untuk memenuhi kebutuhan selama pandemi Covid-19 karena dilihat dari karakteristik tanah di Kabupaten Pangandaran termasuk kategori tanah yang subur. Potensi yang dimiliki Kabupaten Pangandaran harus dimaksimalkan dengan cara meningkatkan poduktivitas petani dalam mengolah lahan. Sektor pertanian menjadi penunjang pariwisata sesuai dengan harapan Pemerintahan Kabupaten Pangandaran sebagai wisata dunia. Banyak kegiatan dari daerah yang lain yang diselenggarakan di Pangandaran dan dapat dijadikan sebagai peluang untuk memasarkan hasil pertanian, khususnya pangan melalui hotel dan restoran. Sektor pertanian menjadi penopang perekonomian masyarakat saat aktivitas bisns secara umum dan pariwisata yang terhenti karena Covid-19, sektor pertanian yang mampu bertahan selama Covid-19.
Petani di Kabupaten Pangandaran merasakan dampak dari adanya pandemi covid-19. Dampak tersebut semakin besar dengan ditutupnya pariwisata Pangandaran banyak hotel, restoran dan rumah makan karena tidak ada pengunjung atau wisataan baik dari manca negera ataupun lokal yang datang ke Pangandaran. Dengan adanya pandemi covid-19 terjadi perubahan pada sektor pertanian di Pangandaran. Petani di Pangandaran harus mampu untuk menyesuaikan diri dengan perubahan tersebut untuk dapat bertahan serta dapat memenuhi kebutuhan kehidupan selama pandemi covid-19.

Tujuan penelitian ini adalah untuk mengetahui: (1) pengaruh covid-19 terhadap petani padi sekitar daerah pariwisata Pangandaran, dan (2) upayaupaya petani padi sekitar daerah pariwisata Pangandaran di era covid-19.

\section{METODE PENELITIAN}

Penelitian ini menggunakan metode kualitatif deskripsi. Menurut Erickson dalam Anggito \& Setiawan (2018), penelitian kualitatif berusaha untuk menemukan dan menggambarkan secara naratif kegiatan yang dilakukan dan dampak dari tindakan yang dilakukan terhadap kehidupan mereka. Hasil 
penelitian kualitatif deskripsi berisi kutipan-kutipan dari data yang berasal dari transkip wawancara dokumen pribadi dan resmi, memo serta gambaran dari rekaman-rekaman resmi lain.

Penentuan informan menggunakan teknik snowball sampling, dimana teknik snowball merupakan suatu teknik metode untuk mengindentifikasi, memilih, dan mengambil ampel dalam suatu jaringan atau rantai hubungan yang lurus (Neuman dalam Nurdiani, 2014).

Fokus penelitian ini adalah upayaupaya-upaya petani padi sekitar daerah pariwisata Pangandaran di era covid-19.

Lokasi penelitian Desa Cibenda, Kecamatan Parigi Kabupaten Pangandaran dipilih secara sengaja karena Desa Cibenda merupakan desa yang berada di daerah pariwisata Pangandaran, dan mata pencaharian masyarakat Desa Cibenda adalah petani padi.

Sumber data primer diperoleh dari hasil observasi lapangan dan wawancara terhadap petani padi di Desa Cibenda dan tengkulak padi di Desa Cibenda. Data sekunder diperoleh dari BPS, buku dan studi literatur.

Analisis data menggunakan model analisis interaktif berupa pengumpulan data, reduksi data, penyajian data, penarikan kesimpulan (Milles dan Huberman dalam Wandi, Nurharsono, Raharja, 2013).

\section{HASIL DAN PEMBAHASAN}

Gambaran Lokasi Penelitian

Desa Cibenda merupakan salah satu desa yang berada di wilayah administratif Kecamatan Parigi, Kabupaten Pangandaran, Jawa Barat. Luas wilayah desa Cibenda pada tahun 2016 seluas $7593 \mathrm{~km}^{2}$ dengan kepadatan 909 orang $/ \mathrm{km}^{2}$. Desa Cibenda berada paling timur dari Kecamatan Parigi, jarak Desa Cibenda ke ibu kota Kabupaten Pangandaran berjarak $7 \mathrm{~km}$. Berdasarkan tinggi permukaan air laut Desa Cibenda berada di ketinggian 3 mdpl (Kecamatan Parigi Dalam Angka, 2018).

Batas wilayah Desa Cibenda sebagai berikut:

Utara : Desa Bojong, Kecamatan Parigi

Selatan : Samudra Hindia

Barat : Desa Ciliang, Kecamatan Parigi Timur : Desa Sukaresik Kecamatan, Sidamulih

Mata pencaharian di Desa Cibenda masih didominasi oleh petani, khususnya untuk petani padi. Luas wilayah Desa Cibenda mencapai 802,43 ha terdiri atas tanah sawah seluas 347 ha dan tanah 
datar seluas 4,43 ha (Kecamatan Parigi dalam Angka 2018).

\section{Usahatani Padi di Desa Cibenda Selama Pandemi Covid-19}

1. Lahan

Petani di Desa Cibenda dalam status kepemilikan lahan sebagian besar yaitu lahan milik sendiri sehingga petani berhak untuk menentukan apa yang akan dilakukan untuk lahannya tersebut, dan bebas untuk menentukan teknologi apa yang akan digunakan untuk mendukung usahatani tersebut, serta bebas untuk menjualbelikannya. Untuk sumber kepemilikan lahan petani di Desa Cibenda sebagian besar berasal dari warisan dan membeli. Untuk lahan warisan petani dapatkan dari turunmenurun dari orang tua petani, sedangkan untuk membeli petani membeli lahan tersebut petani lain yang menjual lahannya.

Kepemilikan lahan pada pandemi covid-19 mengalami sedikit perbedaan dimana pada saat pandemi banyak lahan yang dikelola oleh petani penggarap yaitu dengan lahan sakap. Lahan sakap merupakan lahan yang dikelola oleh petani penggarap dengan izin dari pemilik lahan. Untuk pembagian hasil yaitu untuk petani penggarap sebesar $50 \%$ dan untuk pemilik lahan sebesar
$50 \%$. Walapun lahan yang disakap bukan lahan sawah tetapi lahan ladang atau kering.

2. Tenaga Kerja

Petani padi Desa Cibenda menggunakan tenaga kerja petani itu sendiri, untuk beberapa pekerjaan petani menggunakan tenaga kerja buruh tani. Jika pekerjaan tersebut tidak bisa dilakukan oleh petani sendiri. Petani Desa Cibenda akan memilih buruh tani yang memiliki keterampilan. Walapun buruh tani di Desa Cibenda tidak mengikuti pelatihan tetapi keterampilan buruh tani sangat baik, hal tersebut disebabkan karena pengalaman dari buruh tani tersebut. Pengupahan di Desa Cibenda menggunakan sistem upah harian tidak tetap yang diterapkan pada saat persemaian, penanaman dan panen karena pada saat itu buruh tani hanya bekerja satu hari lalu langsung dibayar oleh pemilik lahan. Pada proses persemainan, penanaman dan panen bisa dikerjakan satu hari jika buruh tani yang dipekerjakan banyak. Untuk sistem upah harian tetap biasanya diterapkan pada proses pengolahan lahan dan pemeliharaan karena pada tahap tersebut pekerjaan bisa dilakukan lebih dari satu hari. 
Buruh tani pada saat pandemi covid-29 di Desa Cibenda semakin banyak karena banyak orang yang dari kota pulang ke desa karena mereka sudah tidak bekerja di kota. Para pendatang baru ini akan untuk memenuhi kebutuhan hidup di desa, mereka akan bekerja apa saja termasuk menjadi buruh tani, walapun keterampilan yang dimiliki sedikit.

\section{Modal}

Modal yang digunakan petani untuk usahatani padi menggunakan modal sendiri, yang petani dapatkan dari hasil penjualan gabah padi panen sebelumnya. Petani akan menyisakan hasil penjualan tersebut untuk penanaman yang akan datang. Pada saat pandemi seperti ini petani mendapatkan bantuan dari pemerintah berupa uang tunai dan sembako. Bantuan uang tunai diberikan kepada petani melalui kantor pos dengan jumlah Rp 300.000 per KK. Dengan uang tersebut petani mendapatkan tambahan modal untuk menanam padi. Berdasarkan sifatnya modal petani menggunakan labor saving capital dimana petani akan menghemat penggunaan tenaga kerja supaya pengeluaran yang dikeluarkan oleh petani sedikit. Petani juga mendapatkan modal untuk usahatani mereka dari meminjam kepada tetangga atau kepada orang lain yang non bank. Petani meminjam uang untuk menambah modal yang sudah ada. Walapun pada saat pandemi ini banyak sekali tenaga kerja yang berada di desa, tetapi petani akan berpikir dalam penggunaan tenaga kerja karena keterbatasan modal yang petani miliki dan apalagi dengan adanya himbauan dari pemerintah untuk menjaga jarak dan tidak berkerumun.

\section{Pengaruh Pandemi Covid-19 Terhadap Budidaya Tanaman Padi}

1. Pengolahan lahan

Petani dalam pengolahan lahan menggunakan traktor, hal tersebut dilakukan untuk menghemat biaya produksi. Walapun pada saat pandemi ini banyak tenaga kerja untuk diperkerjakan. Tetapi dalam pengolahan lahan menggunakan traktor tidak hanya menghemat biaya, tetapi juga lebih efesien dan cepat dalam pengerjaannya. Sedangkan untuk merapihkan pinggir sawah yang tidak bisa dilakukan oleh traktor, maka pekerjaan tersebut dilakukan oleh petani itu sendiri. Proses pengolahan lahan di Desa Cibenda tidak mengalami perubahan, karena menurut informan aktivitas ini dapat berjalan seperti biasa dengan dengan ada tidak adanya pandemi covid-19. 
2. Pembenihan

Bibit yang digunakan oleh petani di Desa Cibenda menggunakan bibit yang tahan dengan air asin, karena letak sawah petani dekat dengan laut. Walapun letak sawah tidak terlalu dekat dengan laut, tetapi air asin bisa masuk ke sawah melewati saluran air yang berasal dari sungai, sungai terhubung dengan laut. Varietas padi yang banyak digunakan oleh petani di Desa Cibenda yaitu INPARI-36 dan NUNGGAL.

Proses pembenihan tidak terlalu terpengaruh oleh pandemi covid-19 karena untuk benih sendiri petani dapatkan dari sisa hasil panen sebelumnya. Petani di Desa Cibenda akan menyisakan hasil panen sebelumnya untuk dijadikan benih pada musim tanam berikutnya.

\section{Persemaian}

Benih yang sudah direndam kemudian benih disemai ke lahan yang sudah disiapkan. Berdasarkan wawancara langsung kepada petani persemaian dapat dilakukan di dua tempat, yaitu lahan yang berada di darat dan lahan yang berada di sawah atau lahan basah. Proses persemaian pada saat pandemi hanya dilakukan oleh petani sendiri dengan bantuan dari istri dan anak-anak petani. Jika sebelumnya petani memperkerjakan buruh tani dalam proses persemaian, tetapi saat pandemi petani dibantu oleh anak-anak petani yang pulang dari kota.

\section{Penanaman}

Bibit yang sudah berumur 21-28 hari di persemaian dipindahkan ke sawah sebelumnya dilakukan pengolahan lahan terlebih dahulu kemudian bibit dipindahkan ke sawah. Petani di Desa Cibenda biasanya melakukan daut (pencabutan bibit di tempat semai) terlebih dahulu, kemudian bibit tersebut langsung ditanam ke sawah. Sebelum ditanam, sawah digarit (membuat jarak tanam) terlebih dahulu untuk mempermudah dalam penanaman nantinya. Jarak tanam yang banyak digunakan oleh petani di Desa Cibenda adalah 30 × $30 \mathrm{~cm}$. Pada saat pandemi covid-19 petani mengurangi buruh tani dalam proses penanaman. Sebelumnya pandemi tenaga kerja buruh yang diperkerjakan 5 orang per 100 bata untuk mempercepat pekerjaan tetapi pada saat pandemi tenaga kerja buruh tani yang diperkerjakan 3 orang per 100 bata. Hal tersebut petani dilakukan untuk menghemat modal karena pada pandemi seperti sekarang ini kebutuhan menjadi mahal dan untuk mengurangi aktivitas sehingga tidak ada kerumunan. 


\section{Pemupukan}

Pemupukan akan dilakukan sebanyak tiga kali, tetapi petani hanya melakukan pemupukan dua kali pada pandemi sekarang ini. Pertama, pada umur tanaman padi 15 hari pupuk yang digunakan urea dan poska dengan perbandingan 2:1. Pemupukan kedua dilakukan pada saat tanaman padi berumur 35 hari pupuk yang digunakan poska dan urea dengan perbandingan 3:2.

\section{Penyiangan}

Petani di Desa Cibenda melakukan penyiangan sebanyak dua kali, yang pertama dilakukan pada saat tanaman padi berumur tiga minggu setelah tanam. Penyiangan ke dua dilakukan pada saat tanaman padi berumur enam minggu. Penyiangan dilakukan dengan gasrok (alat untuk mencabut gulma di sawah).

Penyiangan dilakukan oleh tenaga kerja petani itu sendiri, selama pandemi ini petani lebih banyak dibantu oleh tenaga kerja keluarga karena anak-anak dari petani pulang ke kampung dan menetap lebih lama di desa. Untuk dapat bertahan di desa mereka banyak membantu orang tuanya di sawah. Dalam proses penyiangan tidak memerlukan keterampilan yang khusus hanya memerlukan kerajinan dan keuletan.

\section{Panen}

Panen padi akan dilaksanakan pada saat padi berumur 70-120 hari tergantung pada varietas yang ditanam oleh petani. Berdasarkan wawancara langsung kepada petani, untuk varietas INPARI-36 akan dipanen pada saat padi berumur 70 hari, sedangkan untuk varietas NUNGGAL di panen pada saat berumur 90 hari. Untuk proses panen padi di Desa Cibenda menggunakan sabit dan mesin perontok padi.

Proses panen pada saat pandemi covid-19 mengalami perbedaan dibandingkan dengan panen sebelumnya. Dengan adanya menjaga jarak ketika melakukan panen dan tenaga kerja buruh tani yang banyak dibandingkan dengan panen sebelumnya. Hal tersebut karena banyak orang yang tidak bisa bekerja karena tempat mereka bekerja ditutup untuk sementara selama pandemi.

8. Pasca panen

Gabah yang telah dirontokan dimasukan ke dalam karung kemudian dikeringkan atau dijemur di bawah sinar matahari untuk menurunkan kadar air pada gabah. Proses pengeringan dilakukan selama dua hari jika panas matahari maksimal, sedangkan jika panas matahari tidak terlalu panas pengeringan dilakukan selama tiga hari bahkan bisa 
lebih. Pada saat pandemi petani melakukan proses pengeringan menjadi lama, hal tersebut dikarenakan untuk menjaga supaya padi tetap aman dalam penyimpanan yang lama. Untuk menjaga supaya kebutuhan akan pangan petani terpenuhi selama pandemi. Pada saat pandemi petani dalam proses pengeringan ini lebih menggunakan tenaga kerja keluarga mereka yang ada di rumah dari pada menggunakan tenaga kerja buruh tani.

\section{Pemasaran Padi Sekitar Daerah Pariwisata Pangandaran Selama Covid-19}

1. Menjual hasil panen padi ke tengkulak/pengepul

Petani di Desa Cibenda menjual hasil panen mereka kepada tengkulak, hal tersebut mereka lakukan karena petani tidak tahu akan menjual ke mana jika tidak menjual ke tengkulak. Jika akan menjual gabah padi petani akan memanggil tengkulak untuk datang ke rumah petani. Untuk sistem pembayaran ada yang langsung memberi uang, ada pula yang mengambil dulu gabah jika gabah sudah terjual baru dibayarkan kepada petani.

Sebelum pandemi covid-19 petani akan menjual $70 \%$ dari hasil panen, sedangkan untuk $30 \%$ yang lainnya digunakan untuk kebutuhan sehari-hari dan untuk dikonsumsi. Pada saat pandemi covid-19 petani hanya menjual $50 \%$ dari hasil panen dan sisanya $50 \%$ petani akan disimpan di lumbung padi untuk memenuhi kebutuhan dan untuk konsumsi. Hal tersebut petani lakukan untuk dapat memenuhi kebutuhan petani pada saat pandemi. Petani akan merasa tenang jika di rumah ketersediaan padi tercukupi, petani merasa cemas jika kedepannya terjadi sesuatu yang tidak diinginkan

2. Pariwisata Pangandaran ditutup selama pandemi covid-19

Pemerintah

Kabupaten

Pangandaran mengantisipasi penyebaran virus corona dengan menutup sementara seluruh objek wisata yang ada di Pangandaran. Pemerintah Kabupaten Pangandaran melakukan penutupan sesuai dengan kebijakan dari pemerintah pusat. Penutupan pariwisata Pangandaran berupaya untuk mengurangi kerumunan masa dan meminimalisir mobilisasi warga dari luar kota. Dampak dari penutupan seluruh objek wisata di Kabupaten Pangandaran membuat sebagian besar pedagang yang ada di kawasan obyek wisata memilih untuk tutup termasuk hotel, restoran dan rumah makan karena tidak ada pengunjung yang 
datang. Tengkulak akan menjual beras ke hotel, restoran, rumah makan dan warung kelontongan yang sudah menjadi pelanggan tengkulak.

Setelah ditutup pariwisata Pangandaran yang mengakibatkan hotel, restoran dan rumah makan terpaksa untuk tutup karena tidak ada pengunjung yang datang. Hal tersebut sangat berpengaruh terhadap tengkulak karena pada saat pandemi tengkulak tidak bisa memasarkan dan menjual beras ke hotel, restoran dan rumah makan yang biasanya tengkulak menjual beras kepada mereka. Hal itu yang membuat tengkulak merasa kesulitan pada saat pandemi. Pemasaran beras pada saat pandemi covid-19 hanya dijual ke warung kelontongan yang berada di Pangandaran. Itu pun dengan jumlah yang lebih sedikit dari pada sebelum pandemi. Tidak hanya ke warung kelontongan saja, tetapi tengkulak juga menjual memasarkan beras langsung ke konsumen yang datang ke tempat tengkulak untuk membeli dan itu pun dengan jumlah yang sedikit karena untuk konsumsi peribadi.

\section{Upaya yang Dilakukan oleh Pemerintah}

1. Bantuan langsung uang tunai

Selama pandemi banyak sekali bantuan yang diberikan oleh pemerintah kepada masyarakat termasuk kepada petani di pedesaan. Bantuan tersebut bermacam-macam bentuknya salah satunya dengan bantuan langsung tunai yang diberikan kepada petani di pedesaan. Hal tersebut dirasakan oleh petani padi di Desa Cibenda. Berdasarkan hasil wawancara yang mendapatkan bantuan langsung tunai tidak semua petani mendapatkan, hanya beberapa petani yang mendapatkan. Untuk petani yang mendapatkan merasa terbantu dengan bantuan tersebut. Untuk bantuan langsung tunai ini diberikan secara langsung kepada petani melalui kantor pos Indonesia yang berada di Pangandaran. Jumah bantuan tersebut sebesar 300.000 per KK yang diberikan per bulan selama pndemi covid-19.

2. Bantuan sembako

Bantuan dari pemerintah selama pandemi tidak hanya dalam bentuk bantuan langsung tunai tetapi dalam bentuk sembako. Bantuan dalam semabako ini meliputi: beras, minyak goreng, telur, mie instan, tepung terigu. Bantuan tersebut diberikan kepada petani. Tidak seperti bantuan langsung tunai yang mendapatkan bantuan tersebut hanya sebagian, tetapi bantuan dalam bentuk sembako semua petani mendapatkan bantuan tersebut. Untuk 
bantuan dalam bentuk sembako berasal dari dua sumber bantuan, yaitu bantuan sembako yang berasal dari provinsi dan ada yang berasal dari kabupaten. Sistem bantuan sembako ini dengan menggunakan voucher terlebih dahulu yang dibagikan kepada masyarakat. Kemudian voucher tersebut ditukarkan ke warung kelontong yang sudah bekerja sama dengan pemerintah sebagai distributor.

\section{Upaya yang Dilakukan oleh Petani}

1. Pengurangan tenaga kerja

Pengurangan tenaga kerja dalam usahatani padi di Desa Cibenda merupakan upaya yang dilakukan oleh petani pada pandemi covid-19. Upaya tersebut petani lakukan untuk dapat menghemat modal usaha mereka dan untuk dapat menaati aturan dari pemerintah untuk tidak berkerumun. Dalam hal pengurangan tenaga kerja petani memperhatikan keefisienan dan kecepatan dalam pengerjaan usahatani. Petani akan memilih tenaga kerja buruh tani yang sudah memiliki keterampilan dan pengalaman dalam hal tersebut.

2. Menggunakan tenaga kerja keluarga

Menggunakan tenaga kerja keluarga merupakan upaya yang petani lakukan pada pandemi covid-19. Pada pandemi ini banyak keluarga petani yang berada di kota dan pekerja di kota pulang. Pada saat pandemi banyak orang yang pulang kampung karena sudah tidak ada pekerjaan di kota. Dengan banyaknya keluarga yang pulang ke kampung halaman membuat tenaga kerja keluarga petani semakin banyak. Untuk dapat memenuhi kebutuhan selama di kampung maka mereka akan membantu petani dalam usahatani padi yang petani lakukan. Petani akan menggunakan tenaga kerja keluarga terlebih dahulu dari pada orang lain.

3. Mengurangi pemberian dosis pupuk

Pandemi covid-19 memberikan pengaruh terhadap distribusi pupuk bersubsidi yaitu dengan keterambatan pupuk dan kelangkaan pupuk. Hal tersebut yang membuat petani merasa kebingungan dan kesulitan untuk memperoleh pupuk selama pandemi. Ketersediaan pupuk di agen-agen pupuk bersubsidi tidak ada bahkan petani menunggu pupuk datang dengan waktu yang lama. Keterambatan dan kelangkaan pupuk disebabkan karena akses jalan banyak yang ditutup selama pandemi. Salah satu upaya yang dilakukan oleh petani selama pandemi ini mengurangi pemberian dosis pupuk selama budidaya. 
4. Meminjam uang ke tetangga atau ke non bank

Petani akan meminjam uang ke tetangga atau non bank untuk dijadikan sebagai modal petani dalam berusahatani dan untuk memenuhi kebutuhan seharihari petani. Pada saat pandemi sekarang ini untuk mendapakan modal dan untuk memenuhi kebutuhan sangat susah. Dengan meminjam modal setidaknya petani terbantu, uang hasil meminjam akan digunakan sebagai tambahan modal.

5. Pengurangan penjualan gabah padi

Petani di Desa Cibenda akan menjual hasil panen mereka, sebelum pandemi covid-19 petani akan menjual sebanyak $70 \%$ dari hasil panen tersebut dan sisanya sebanyak $30 \%$ akan mereka simpan di lumbung padi yang ada di rumah petani. Sisa penjualan tersebut petani digunakan untuk memenuhi kebutuhan sehari-hari sampai menunggu panen selanjutnya. Pada saat pandemi petani hanya $50 \%$ dari hasil panen tersebut, dan sisanya sebanyak 50\% masukan ke lumbung padi. Hal itu petani lakukan untuk menjaga ketersediaan pangan di rumah mereka dengan menyimpan lebih banyak padi di lumbung padi karena petani berpikir selama ada beras di rumah mereka akan merasa tenang. Walapun mereka tidak punya uang unuk membeli lauk, tapi setidaknya mereka mempunyai beras di rumah dan cukup untuk memenuhi kebutuhan.

6. Menanam tanaman yang lain dengan jumlah penjualan yang dikurangi

Petani di Desa Cibenda tidak hanya menanam tanaman padi tetapi juga menanam tanaman yang lain seperti kacang panjang, kacang tanah, kacang kedelai, singkong, ubi jalar, dan lain-lain. Hal tersebut petani lakukan untuk dapat memenuhi kebutuhan sehari-hari. Petani menanam tanaman tersebut untuk dijual biasanya petani akan menjual hasil panen tanaman tersebut ke tetangga atau ke tukang sayur yang membutuhkan tanaman tersebut. Sebelum pandemi covid-19 petani akan menjual tanaman tersebut dengan besaran $60 \%$ dari hasil panen tanaman dan sisanya $40 \%$ akan petani konsumsi sendiri. Namun, dengan adanya pandemi covid-19 memberikan perubahan persentase penjualan petani menjadi 70\% untuk dikonsumsi dan sisanya $30 \%$ untuk dijual. Hal itu petani lakukan untuk memenuhi kebutuhan di rumah terlebih dahulu baru jika ada lebih petani akan menjual hasil panen dari tanaman tersebut. 


\section{KESIMPULAN DAN SARAN}

Pandemi covid-19 memberikan pengaruh terdapat usahatani padi di Desa Cibenda Kecamatan Parigi Kabupaten Pangandaran. Untuk proses budidaya pengaruh pandemi covid-19 sangat dirasakan pada distribusi pupuk yang terlambat dan kelangkaan pupuk bersubsidi. Hal tersebut yang menghambat petani dalam proses budidaya. Untuk proses yang lain seperti pengolahan lahan, pembenihan, persemaian, penanaman, penyiangan, panen dan pasca panen mengalami sedikit perubahan terutama pada tenaga kerja selebihnya tidak terlalu berpengaruh.

Pengaruh yang sangat besar dirasakan pada pemasaran padi hasil panen karena pada saat pandemi pariwisata Pangandaran terpaksa untuk tutup yang mengakibatkan hotel, restoran dan rumah makan pun ikut tutup. Dengan penutupan pariwisata membuat tengkulak tidak bisa menjual padi hasil panen ke hotel, restoran dan rumah makan. Tengkulak juga tidak dapat memasarkan padi ke luar daerah Pangandaran karena akses jalan banyak yang ditutup. Oleh karena itu, selama pandemi ini petani hanya menjual padi di dalam pangandaran dengan menjual ke warung kelontongan dan langsung ke konsumen.
Selama pandemi covid-19 petani di Desa Cibenda melakukan beberapa upaya untuk dapat memenuhi kebutuhan petani. Upaya tersebut ada yang berasal dari pemerintah dan ada yang berasal dari petani sendiri. Untuk upaya yang dilakukan pemerintah selama pandemi covid-19 yaitu dengan adanya bantuan langsung tunai dan bantuan dalam bentuk sembako. Sedangkan untuk upaya yang dilakukan petani selama pandemi covid19 yaitu sebagai berikut 1) pengurangan tenaga kerja dalam usahatani padi, 2) menggunakan tenaga kerja keluarga, 3) mengurangi dosis pemberian pupuk, 4) meminjam uang ke tetangga atu non bank, 5) pengurangan penjualan gabah padi, dan 6) menanam tanaman yang lain dengan jumlah penjualan yang dikurangi.

Saran yang diberikan untuk penelitian ini yaitu pemerintah harus membantu petani dalam ketersediaan pupuk bersubsidi dengan jumlahnya diperbanyak sehingga tidak terjadi kelangkaan, pemerintah harus memberikan bantuan secara merata sehingga semua petani mendapatkan bantuan tersebut, pemerintah membantu petani dalam proses pemasaran hasil panen petani, pemerintah harus bekerja sama dengan bulog untuk dapat memasarkan hasil panen petani. 


\section{UCAPAN TERIMA KASIH}

Pada kesempatan ini, kami mengucapkan terimakasih kepada petani padi di Desa Cibenda Kecamatan Parigi Kabupaten Pangandaran yang telah memberikan izin untuk penelitian.

\section{DAFTAR PUSTAKA}

Anggito, A., \& Setiawan, J. (2018). Metodologi Penelitian Kualitatiif. Sukabumi: CV Jejak.

Badan Perencanaan Pembangunan Nasional.2008. Dampak parwisata terhadap perekonomian Nasional.[internet].Diakses 15 Agustus 2020, dari http//:kppo.bappenas.go.id

Badan Perencanan Pembangunan Daerah .2018.Rencana Pembangunan Jangka Menengah Daerah Tahun 2016-2021 Kabupaten Pangandaran.[internet].Diakses 20 Agustus 2020.

BPS. (2018). Kecamatan Parigi Dalam Angka 2018. Ciamis: Badan Pusat Statistik Kabupaten Ciamis.

BPS. (2018). Kabupaten Pangandaran Dalam Angka 2018. Ciamis : Badan Pusat Statistik Kabupaten Ciamis.
Dhalyana, D., \& Adiwibowo, S. (2013). Pengaruh Taman Wisata Alam Pangandaran Terhadap Kondisi Sosial Ekonomi Masyrakat. Sosiologi Pedesaan, 01(03, 182199. Fauzi, P., Bakhri, S., \& ahmah, A. A. (2019). Pembangunan Pariwisata di Kabupaten Pangandaran Pasca Pemekaran. Ekonomi dan Perbankan syari'ah, 11(1), 77-94.

Luktaningsih, A. (2013). Perkembangan Konsep Pemasaran : Implementasi Dan Implikasinya. Maksipreneur, 3(1), 21-3.

Mahmud, A. (2016). Adaptasi Sebagai Strategi Bertahan Hidup Manusia. Ar-Risalah, XVII(1), 51-61.

Nurdiani, N. (2014). Teknik Sampling Snowball. comtech, 5(2), 11101118 .

Rozen, N., \& Kasim, M. (2018). Teknik Budidaya Tanaman Padi Metode SRI. Depok: PT RajaFrafindo Persada.

Saeri, M. (2018). Usahatani Dan Analisisnya. Malang: Universitas Wisnuwardhana Malang Press ( Unidha Press ).

Wandi , S., Nurharsono , T., \& Raharja, A. (2013). Pembinaan Prestasi Ektrakurikuler Olahraga Di Smakarangturi Kota Semarang. Journal Of Physical Education, Sport, Health And Recreations, 524-535. 